\title{
PERSONAL INSOLVENCY AND IMPLICATIONS FOR CREDIT INSTITUTIONS
}

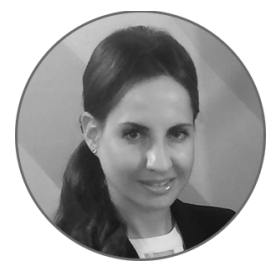

Article history:

Received 23 January 2017 Received in revised form 31 January 2017

Accepted 22 February 2017

Translated 13 November 2017

Available online 14 December 2017

JEL classification: C21, E41, E58, G01

\begin{abstract}
Importance Having been adopted in 2015, personal insolvency regulations significantly influenced the supply structure in the lending market, and dramatically changed banks' approaches to dealing with difficult customers, especially in consumer lending.
\end{abstract}

Objectives The research analyzes strengths and weaknesses credit institutions face as a result of the enforcement of personal insolvency regulations, nature of changes in banks and debtors' interaction models, and transforms principles of lending policies in line with existing economic realities.

Methods I apply methods of logic, economic analysis to study banking risks associated with insolvency of individual borrowers.

Results I fundamentally evaluate principles of personal bankruptcy laws so as to determine possible banking risks at each stage of bankruptcy proceedings. Having analyzed cause-and-effect perspectives, I identified procedural and economic difference of debt restructuring processes and sale of debtors' property that took place as part of bankruptcy proceedings.

Conclusions and Relevance The adoption of bankruptcy regulations will make banks be more tolerable to troubled borrowers seeking for debt restructuring. Banks seldom exercise their entitlement for suing bankrupt debtors, since this reduces interest, other income and the amount to be repaid. The analysis unravels the personal Keywords: bankruptcy, citizen, bank risk, insolvency procedure in terms of vulnerable aspects and allows to understand advantages banks may enjoy if they restructuring

๑) Publishing house FINANCE and CREDIT, 2017

The editor-in-charge of this article was Irina M. Vechkanova Authorized translation by Irina M. Vechkanova

\section{Introduction}

Nowadays every economically active Russian owes about RUB 141.7 thousand to credit institutions, according to RBK Group. It noticeably differs from trends of the previous years. For instance, as of 2014, 2013, 2012 and 2011 outstanding loan balances amounted to RUB 120 thousand, 116.7 thousand, 85 thousand and 60.8 thousand respectively. Hence, the loan debt-to-income ratio of

\footnotetext{
${ }^{\dagger}$ For the source article, please refer to: Юсупова О.А. Банкротство граждан и его последствия для кредитных организаций. Финансовая аналитика: проблемы и решения. 2017. Т. 10. Вып. 4. С. 403-417. URL: https://doi.org/10.24891/fa.10.4.403
}

the Russian population has almost tripled for the recent five years.

Statistically, one in four Russians has a nonperforming loan borrowed in cash. Credit card debts are common for one in six people, auto loan debts for one in ten people, and mortgage debts for one in 25 people. Furthermore, debt burden still remains high per debtor, i.e. 1.8 against 1.2 year-on-year. This indicator grows as debtors' financial position deteriorates due to the Ruble devaluation, increasing inflation and unemployment. 
Indicators of overdue debts and loans as a whole also follow a pessimistic scenario, especially in retail lending (Fig. 1).

The above figures are very indicative of an outstripping growth in relative indicators of overdue debts of individuals as compared with identical indicators of deposited amounts. While as of October 1, 2013 overdue balances of retail loans in a certain loan portfolio exceed the identical indicator in the overall portfolio of deposited amounts by 0.89 percent (with the indicators are 3.6 and 4.49 percent respectively), this gap triples as of October 2016 up to 2.78 percent (5.76 and 8.54 percent respectively).

So, the market not only sees increasing overdue debts on all types of loans but also faces a bigger challenge of an outstripping growth in the relative amount of nonperforming loans in the retail lending portfolio. The collectibility of those debts raises concerns considering numerous unsecured loans.

Once any nonperforming signs emerge, they not only downgrade the quality of banks' loan portfolios, but also oblige the banks to make more provisions for possible losses. Such provisions have grown from 6.18 to 8.74 percent as part of loan portfolios for two years. That is, provisions cover lower percentage of nonperforming loans, with the growth being incommensurable to an increase in overdue amounts.

As I have already mentioned, there may be two causes. Banks may overstate the factual quality class of loans that is verified through credit monitoring, or actively manage overdue debts inter alia by selling them to debt collection agencies so as to improve the quality of their loan portfolio [1].

Personal bankruptcy proceedings became another method for handling nonperforming loans in October 2015 in accordance with the adopted principles of Federal Law On Insolvency (Bankruptcy) of October 26, 2002 № 127-Ф3. Those proceedings invoked an ambiguous response of bankers and mala fide debtors. Bankers interpreted them as a more tolerant treatment of doubtful debtors who solicit debt restructuring. Banks used to restructure debts with some reluctance since restructured or refinanced loans required banks to make bigger provisions for possible losses, more than ordinary ones. Mala fide debtors believed the new procedures would legitimately purify them from their financial sins.

What are strengths and weaknesses of the law for credit institutions that are seriously exposed to the risk? What behavioral models of banks and debtors shall be adjusted to new circumstances? What aspects of lending policies do banks modify in line with the current economic situation?

Before answering the above questions, I shall emphasize that the personal bankruptcy institution is a novelty as opposed to bankruptcy of legal entities and sole proprietors. The novelty came into being about a year ago raising multiple disputes before it entered into effect. Disputes and arguments still continue as seen in researches by such authors as V.I. Gladkikh [2], P.E. Gubin [3], K.B. Koraev [4], V.V. Sergeev [5], E.E. Uksusova [6, 7] et al. ${ }^{1}$

In fact, the institution of personal bankruptcy proves to be quite complicated for both court-appointed administrators and its parties, i.e. creditors (banks) and debtors (individuals).

As court practices show, mala fide debtors were disappointed with the new law and its principles since they still blocked fraudulent bankruptcy schemes. Debtors intended to conceal factual information about their assets from court-appointed administrators and creditors (banks) assuming that the court was allowed to relieve individuals from

\footnotetext{
${ }^{1}$ Belyaeva O. [Personal bankruptcy]. Yuridicheskaya gazeta $=$ Legal Newspaper, 2011, no. 18. (In Russ.); Butorin A.E. [Retail lending: Have expectations of banks and customers been met?]. Yuridicheskaya rabota $v$ kreditnoi organizatsii = Legal Work in the Credit Institution, 2014, no. 3. (In Russ.); Zheleznyak A. [Personal bankruptcy. Genuine goals and the first enforcement experience]. EZh-Yurist, 2016, no. 22, p. 5. (In Russ.); Kirillovykh A.A. [Personal bankruptcy: the future of this legal institution]. Zakonodatel'stvo i ekonomika = Legislation and Economy, 2011, no. 3. (In Russ.); Lazareva N. [Personal bankruptcy: Directions for further development]. EZh-Yurist, 2014, no. 15, pp. 9-10. (In Russ.); Slesarev $\mathrm{S}$. [A riot on board of a bankrupt ship]. Administrativnoe pravo $=$ Administrative Law, 2016, no. 2, pp. 27-32. (In Russ.); Kharitonov G.A. [Challenging issues of personal bankruptcy proceedings]. Arbitrazhnyi upravlyayushchii = Court-Appointed Administrator, 2016, no. 3, pp. 35-38. (In Russ.)
} 
debts and liabilities by assessing whether they were exposed to circumstances ruling out such relief.

Furthermore, the law sets out circumstances which survive bankruptcy proceedings. The principles are promulgated in Article 213.28 of the Federal Law On Insolvency (Bankruptcy). For instance, the individual is not relieved from his/her obligations if:

- the individual is charged with criminal or administrative offense for unlawful activities during the bankruptcy proceedings, deliberate or fraudulent bankruptcy (there is a court ruling);

- the individual fails to submit necessary information or provides deliberate misrepresentation on his/her personality, property and this fact is established to satisfaction of the court;

- the court establishes that the individual acted in an unlawful manner upon origination or fulfillment of the liability underlying the debtor's claim. Such unlawful actions include fraud, fraudulent avoidance of taxes or repayment of debts, submission of deliberate misrepresentations to the creditor in order to obtain a loan, concealment or deliberate destruction of property.

The above circumstances will become issues in proof in court proceedings and underlay the respective court decision. T. Zhukova ${ }^{2}$, A. Sorokin ${ }^{3}$, M.V. Telyukina [8], V.N. Tkachev [9] spotlight this aspect in their articles.

Nevertheless, bona fide individuals understand the strengths of the law. First of all, the debtor can be eligible to personal bankruptcy as enshrined in the law, i.e. debt restructuring, sale of property, out-of-court agreement.

For instance, the property sale procedure allows the debtor to fulfill obligations and subsequently solve all financial problems and settle up debts. The settlement of obligations will entail the sale of the entire property and fair distribution of proceeds among creditors, including banks. If the proceeds are

\footnotetext{
${ }^{2}$ Zhukova T. [Financial sanctions in personal bankruptcy]. EZh-Yurist, 2015, no. 10, pp. 8-12. (In Russ.)

${ }^{3}$ Sorokin A. [Personal bankruptcy]. Zhilishchnoe pravo $=$ Housing Law, 2016, no. 1, pp. 47-52. (In Russ,)
}

insufficient, the debtor's obligations shall be discharged upon the court decision.

Following this scenario, lending banks are trapped in a difficult situation as they lose the possibility of collecting the total debt. Furthermore, if the debtor's property is sold, the proceeds shall be distributed among the debtor's creditors on a pro-rata basis. Otherwise outstanding amounts are not covered completely.

Currently, the law is not very popular among debtors and creditors. According to non-profit partnership Avangard Association of Court-Appointed Administrators, commercial courts of the Omsk oblast received 1,047 bankruptcy applications (totally from legal entities, individuals, sole proprietors) within the effective period of the law. Novosibirsk commercial courts received 1,596 bankruptcy applications, i.e. 30 percent more.

During the first month of the law (October 2015), the Omsk commercial courts received 45 bankruptcy applications and 170 ones for the first quarter of 2016. Thus, about 50 bankruptcy applications are filed monthly. This shows an upward trend, though not being overwhelming in numbers since debtors have to pay for the court-appointed administrator's services the court engages to handle bankruptcy proceedings. Banks seldom exercise their legitimate right for filing bankruptcy claims against their debtors since it cuts banks' interest and other yields and has a strong likelihood of reducing the outstanding amount due from the principle.

Considering the above reason, the banking sector tends to deal with debtors independently and out of court. However, debtors more often than not resort to the court and claim their personal bankruptcy as envisaged in article 213.5 of the law. They understand advantages the procedure provides and try to get a fresh start after their debts are forgiven.

In some cases, the law obliges debtors to resort to the court and initiate bankruptcy proceedings (Fig. 2).

In this respect, if we differentiate the debtor's right and obligation to resort to the commercial court and initiate its personal bankruptcy proceedings, as the law sets forth, we can conclude that all large 
loans exceeding RUB 500 thousand de facto fall within the scope of the personal bankruptcy institution. Thus, creditors' claims are satisfied partially, rather than totally, with available assets of the bankrupt. As a result, banks' losses may exceed those ones as though they deal with defaulting borrowers on their own.

Operating losses of a bank shall not include losses on secured loans, including mortgages, since civil laws on bankruptcy require to satisfy secured lenders' claims first using the pledged property. I omit certain details in this article since they generally coincide with ordinary foreclosure of pledged property as part of a civil lawsuit between the bank and the borrower concerning a secured loan, except for the need to cover balances of preferential creditors' loans using the property and pay for services of the court-appointed administrator and parties it involves.

If the commercial court accepts a bankruptcy claim, the debtor is subject to procedures stipulated in Article 213.2 of the law and intended for different purposes. It sets out an exhaustive list of the procedures, including:

- personal debt restructuring;

- sale of the individual's property;

- settlement.

I focus on the substance of each procedure so as to identify positive and negative effects they may have on banks and credit risk.

A settlement is a procedure in bankruptcy proceedings that may be initiated at any stage of a lawsuit. It is intended to put an end to litigation by ensuring the agreement of the creditor and debtor. The settlement has the equivalent effect as if the borrower approaches the bank, without prejudicing the bank's interests.

As proved with arbitration practices for the duration of the law, restructuring is the most frequent remedy the court imposes on the borrower. It is applied to the individual in order to recover his/her solvency and the ability to pay to creditors in accordance with a respective scheme.
It is noteworthy that bankruptcy procedures impose the other approach to debt restructuring in comparison with that the bank carries out internally once the borrower approaches the bank (creditor) on a pre-trial basis. What differentiates a trial and pre-trial approval of debt restructuring decision? What implications may arise for the bank and the borrower?

In both cases debt restructuring is applicable only to those borrowers who retain sources of income but their loan burden hinders their repayment of the loan balance. Debt restructuring helps the individual solicit a practicable and feasible repayment schedule.

Banks may be exposed to the risk that court-based debt restructuring will apply to those debts involved into bankruptcy proceedings with the creditors. To be entered into the register of preferential creditors' claims and participate in the first meeting of creditors, creditors in bankruptcy proceedings, including banks, with their claims being secured with the individual's property, are entitled to lodge a claim against the individual within two months from the date when the personal bankruptcy application is satisfied as per Article 213.7 of the law. It is unlikely but still probable that the bank may violate the period the law prescribes for its involvement into the proceedings, thus not being listed as one of the creditors.

As for positive effects on banks, law-makers introduce a limited grace period of three years (two years in exceptional cases). It prevents too protracted proceedings. In the mean time, when the borrower approaches the bank out of court and solicit debt restructuring as proved in my research, the procedure may take less than three years to cover the real credit risk of the bank ${ }^{4}$. In this case, once the court rules that the debt shall be restructured, the credit risk of the bank increases, and the established period of debt restructuring becomes inadequate to the real risk exposure.

\footnotetext{
${ }^{4}$ Yusupova O.A. [Managing nonperforming loans in the commercial bank's portfolio]. Innovatsionnaya ekonomika i obshchestvo = Innovative Economy and Society, 2016, no. 2, pp. 81-88. (In Russ.)
} 
It is difficult to unambiguously interpret the legal requirement that all creditors shall agree upon the debt restructuring plan. This is not a guarantee that the bank's needs will be satisfied under the adopted repayment schedule. The fact is that decisions are made by voting at meetings of creditors. The number of votes depends on the amount due to a certain creditor on the list.

The debtor may have several unequal loans with different banks, concurrently owing money to other parties, other than credit institutions. In this case, there is a strong likelihood that terms of the court-appointed and equitable debt restructuring plan will come short of the one if the borrower approaches the bank out of court.

It is also worth mentioning that the list of creditors may include decision-making parties (the bankrupt owes the biggest amounts to them) and their receivables are formalistic. It happens in case of fraudulent or deliberate bankruptcy, which cannot be established or proved in court. Nevertheless, the law empowers the court-appointed administrator and actively involved creditors to gather information about the debtor.

In the course of its performance, the court-appointed administrator shall analyze previous deals of the debtor (at least three or more years retrospectively) and test them for validity (repayment).

If transacting parties are suspected in any malpractice, the deals shall be challenged in at court as principles of Article 10 of the Civil Code of the Russian Federation forbid exercising civil rights with the intention of damaging the other person, any unlawful activities and deliberate misuse of civil rights (abuse).

The law promulgates what conditions shall be met to approve a debt restructuring plan. However, it is evident that the statutory list of such conditions may appear much shorter in practice in comparison with those conditions the lending department of the bank takes into consideration in agreeing and approving the plan (Fig. 3).
According to available data, an approval of a debt restructuring plan in trial requires numerous conditions to be met concurrently. They are common for all debtors involved in bankruptcy proceedings, while the debt restructuring procedure in banks sets up more stringent and extensive requirements to borrowers, being specific in each case and consistent with the bank's strategy for lending.

It is noteworthy that the commercial court makes the final decision in bankruptcy lawsuits, while the bank determines whether it is possible and reasonable to restructure debts in case of no bankruptcy proceedings. In the latter case the bank makes a decision and sets up conditions after it reasonably assesses the credit risk by analyzing quantitative and qualitative indicators, borrower's creditworthiness and financial scenarios considered by underwriting specialists having professional knowledge of lending practices. In case of litigation, it is the debtor who outlines the plan and subsequently coordinates it with creditors, with the court giving the final resolution.

Banks may possibly suffer from the court-based debt restructuring as the law does not foresee an option when the court is to approve the plan in case creditors fail to reach an agreement. This option is practicable if debtors propose the debt repayment schedule but creditors refuse to accept it. The court is empowered to approve the debtor's schedule and set up a limited period for its enforcement in line with available evidence. This extension period may take two years if the court is sure that the option will be more lucrative for the creditors that the immediate sale of the debtor's property.

It should be kept in mind that the court and banks may assess the credit risk in a different way. However, after the debt repayment plan is approved, creditors' claims may be lodged only as the plan provides for this. As per the law, creditors may not require the reimbursement of their losses incurred to the plan approbation.

After the commercial court rules to satisfy the individual's bankruptcy application and restructure the respective debt, forfeitures (penalties, charges) and other financial sanctions 
shall cease. This scenario is impossible if the individual addresses the bank.

In case of bankruptcy, interests on claims of the creditor in bankruptcy are charged at the refinance rate, being significantly lower than interests under a loan agreement if the bank deals with nonperforming loans on its own.

As for positive effects of court-based debt restructuring on banks, individuals are bound to handle their property and manage their money in other accounts or deposits upon written consent of the court-appointed administrator, thus mitigating risks creditors in bankruptcy are exposed to if debtors attempt to conceal property.

The individual is also bound to report on considerable changes in his/her property and send a written notice to creditors in bankruptcy within 15 days such changes occur. Relevant criteria are set forth in the debt restructuring plan and approved by the respective credit institution.

Another advantage for banks is that the law permits creditors in bankruptcy to apply to commercial courts for amending the individual's debt restructuring plan if his/her financial position gets better, i.e. the debt restructuring plan is not constant.

If the court-appointed administrator does not receive any debt restructuring plan of the individual or the meeting of creditors declines the plan and the court dismisses the plan on its own (as I mentioned above), the court qualifies the individual as bankrupt.

In such circumstances, the law prescribes the individual property sale procedure, which may initially last for six months and rightfully extended.

The property sale is a recovery procedure intended to satisfy creditors' claims proportionately.

During this rather protracted period, the court can rule to temporarily forbid the individual's exit from the Russian Federation as long as the procedure are in progress, provided the court has an appropriate application and reasons. The bank is not authorized to do so dealing with its debtors.
During the sale procedure, the individual's property is aggregated in a pool of bankruptcy assets. It enables the bank to cover amounts due from unsecured and most risky loans, which account for a greater portion of nonperforming debts, using the individual's sole or marital property (including property shared with the former spouse).

Bankruptcy assets may also include the individual's property, which comprises his/her share of marital property. The lending bank is empowered to request the individual's share in the marital property for foreclosure.

Property exempt from foreclosure makes the only exception. It is excluded out of bankruptcy assets, being corroborated with the court order. As per Article 446 of the Civil Code of the Russian Federation, such foreclosure exempt property includes:

- household items, possessions for non-shared use (clothing, shoes and so on), other than jewelry and other luxury items;

- food;

- fuel the debtor's family needs to prepare everyday meal and generate heating for their house;

- motor vehicles and other possessions the debtor needs due to his/her disability;

- prizes, State awards, honorable and commemorative distinctions bestowed to the debtor.

Upon a reasoned application of a concerned party, the court is entitled to exclude property, which is not listed in the Article and subject to foreclosure, out of bankruptcy assets. It is important that proceeds from the sale of the property will not cover the bank's claims. Total value of the individual's property out of bankruptcy assets shall not exceed RUB 10 thousand.

Hence, the bank benefits from the debtor's property sale in two cases:

- if the property outvalues the bank's claims;

- if the bank deals with the debtor less effectively, i.e. the bank has no right to initiate foreclosure in 
relation to the debtor's property (including shared property) so as to repay unsecured loans; the bank has no right to prevent the debtor from leaving the country, disposal of deposits and current accounts, etc.

In other cases, the bank's financial interests are infringed if bankruptcy assets are used to cover the debtor's payables since the funds shall be distributed among all creditors proportionately.

The enforcement of the law raises many questions and disputes among parties to bankruptcy proceedings - debtors, creditors, court-appointed administrators:

- how shall parties avoid violating timelines when entries to the Uniform Federal Register of Bankruptcy are released, if there is no taxpayer's identification number (INN in Russian) and individual insurance account number (SNILS in Russian)?;

- may foreclosure be initiated and imposed on the accumulated savings of the insured?;

- is the bankrupt's property search procedure properly established outside Russia?;

- how is a property share put on auction if the property is owned by the debtor's relatives and so on?

These and other questions caused that Chapter 10, as introduced by the Federal Law on June 29, 2015 and effective from October 1, 2015, was amended many times within a year time.

Three months after the law had come into effect, on December 29, 2015, another law was adopted to supplement the Chapter. On June 23, 2016, law makers passed another Federal Law that came into effect in December 2016 and set up a rule implying that, if the court accepts the debt restructuring plan, the individual is entitled to open a special bank account and use monetary funds without the court-appointed administrator's consent within RUB 50 thousand amonth and the court may increase it upon the debtor's request. It mirrors law-makers' more tolerant and loyal attitude to mala fide payers than it was as of the effective date of the law.

The personal bankruptcy legislation is being developed, with its principles being adjusted and specified on an ongoing basis:

- Federal Law of July 3, 2006 edits bankruptcy principles concerning secured creditors;

- fundamental principles of the Russian laws on notaries were supplemented with principles on notaries' authority in bankruptcy proceedings in relation of a deceased person or person declared to be deceased;

- some amendments were made to the Code of Administrative Offenses of the Russian Federation;

- on October 13, 2015 (several weeks after the effective date of the law), Resolution of the Plenum of the Supreme Court of the Russian Federation of October 1, 2015 № 45, On Some Issues of Enforcement of Personal Insolvency (Bankruptcy) Procedures.

Factors below prevent many individuals from applying to commercial courts:

- a vast array of documents to support the application, which individuals are unable to collect on their own. In addition to documents prescribed by the procedural laws, debtors should submit the following ones:

- documents supporting the existing indebtedness, basis for its origination, individual's inability to satisfy creditors' claims entirely;

- lists of creditors and debtors of the individual;

- property inventory;

- copies of documents corroborating the individual's title for the property;

- copies of documents on the individual's transactions with real estate, securities, interest in share capital, motor vehicles, and transactions worth more than RUB 300 thousand, within three years up to the application date; 
- extracts from the register of the entity's shareholders (members), if any, and other documents;

- upon the completion of the bankruptcy procedure, payment for the court-appointed administrator services as the fixed amount of RUB 25 thousand (as per paragraph 3, Article 20.6 of the law), which can be increased in line with the scope and complexity of the procedure, compensation to other parties involved by the court-appointed administrator as per paragraph 6, Article 213 to exercise its authority [10]. Monetary funds for compensation are deposited with the commercial court (paragraph 4, Article 213 of the law). It is necessary to add expenses for information coverage of the bankruptcy procedure (paragraph 4, Article 123.7 of the law);
- payment of the State duty. Prior to 2017, the State duty for bankruptcy applications to commercial courts amounted to RUB 6,000, without being differentiated by applicant - an individual or legal entity. Nowadays it costs RUB 300 for individuals and RUB 6,000 for legal entities.

According to the Central Bank of the Russian Federation, as of December 1, 2016, retail loans with overdue balances exceeding 90 days account for 9.7 percent out of total loans. In a portfolio of retail loans, unsecured retail loans have the highest specific weight of about 79 percent. The relative value of overdue loan balances is higher than the average one in the portfolio - 15 percent. Thus, loans in the portfolio are likely to be involved into bankruptcy proceedings. A 20 -fold decrease in the State duty for bankruptcy proceedings is another trigger. 


\section{Figure 1}

Trends in overdue payables, percentage points

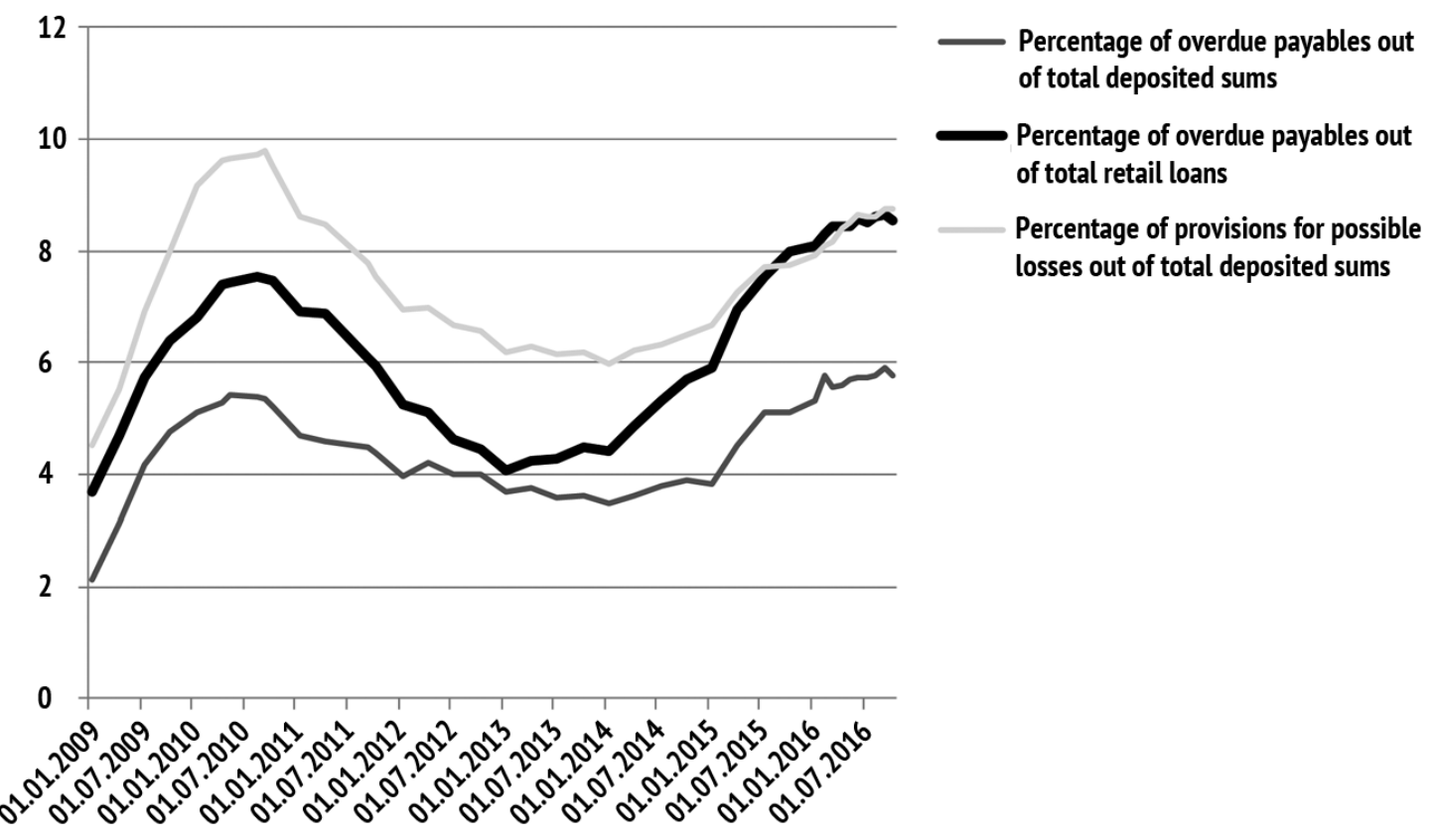

Source:Central Bank of the Russian Federation 
Figure 2

Debtor's rights and obligations in case of the bankruptcy proceedings initiated by the debtor

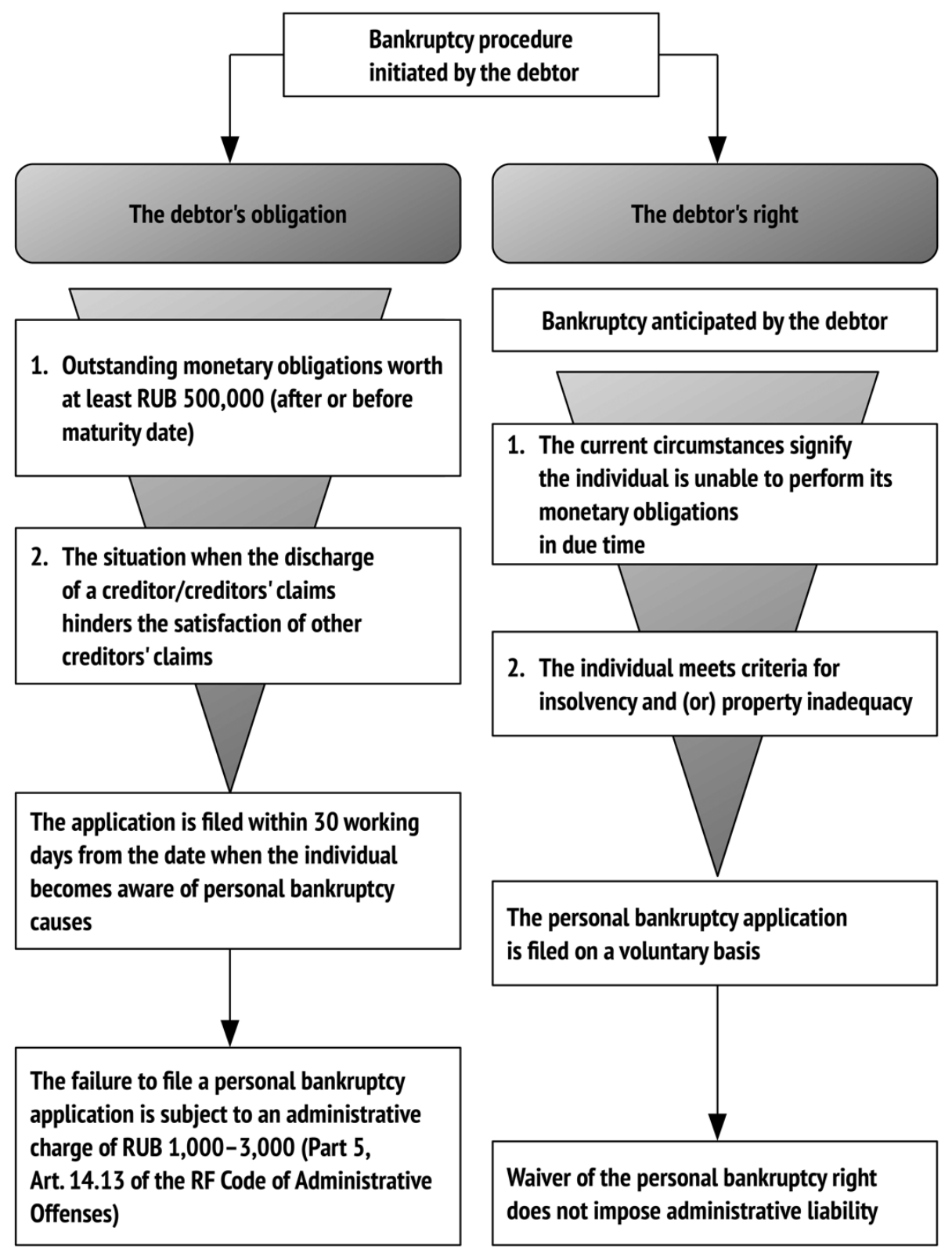

Source: Authoring 


\section{Figure 3}

Comparative analysis of debt restructuring terms

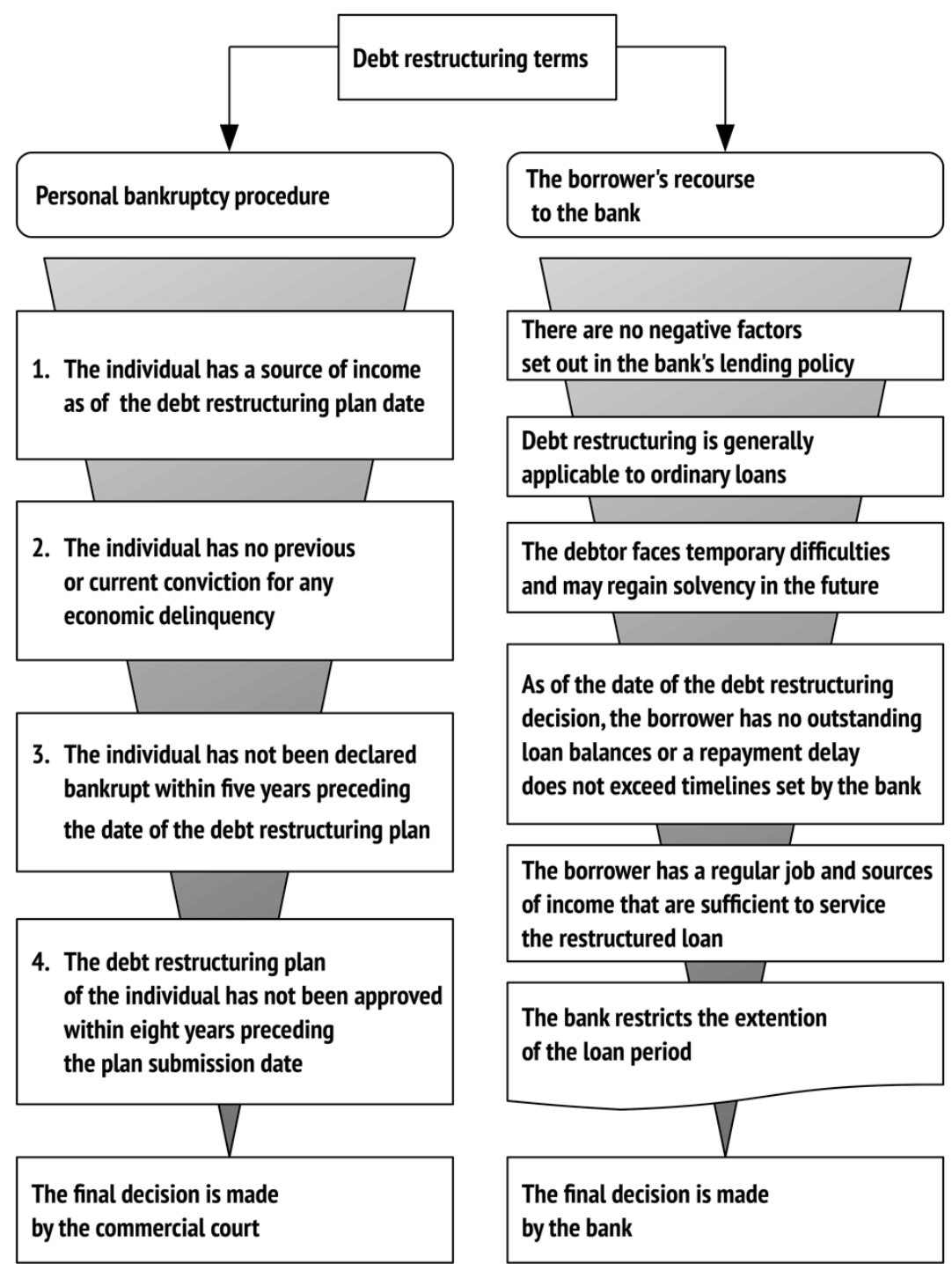

Source. Authoring

\section{Acknowledgments}

I express my deep gratitude to Valentin N. GONCHAROV, Doctor of Economics, Professor, Head of the Department for Corporate Economics and Human Resource Management, for his advice and valuable comments on the article.

\section{References}

1. Yusupova O.A. [Transformation of monitoring in bank lending]. Innovatsionnaya ekonomika i obshchestvo = Innovative Economy and Society, 2014, no. 3, pp. 87-95. (In Russ.)

2. Gladkikh V.I., Sukharenko A.N. [Countering illegal bankruptcy of individuals]. Bezopasnost' biznesa= Business Security, 2016, no. 2, pp. 42-46. (In Russ.) 
3. Gubin P.E., Smirnykh A.G. [Personal insolvency: balancing the debtor and lender's interests]. Predprinimatel'skoe pravo = Entrepreneurial Law, 2010, no. 4. (In Russ.)

4. Koraev K.B. [The principal idea of personal bankruptcy law]. Rossiiskaya yustitsiya = Russian Justitia, 2014, no. 7, pp. 54-61. (In Russ.)

5. Sergeev V.V. [Issues of legislative regulation of the personal bankruptcy procedure]. Bankovskoe pravo $=$ Banking Law, 2012, no. 5, pp. 14-19. (In Russ.)

6. Uksusova E.E. [Cases of public interests protection]. Rossiiskaya yustitsiya = Russian Justitia, 1997, no. 11, pp. 42-44. (In Russ.)

7. Uksusova E.E. [Determining the appropriate court procedure for civil cases]. Zhurnal rossiiskogo prava = Journal of Russian Law, 2009, no. 6, pp. 77-92. (In Russ.)

8. Telyukina M.V. [Personal insolvency]. Zakonodatel'stvo = Legislation, 2001, no. 1, pp. 16-21. (In Russ.)

9. Tkachev V.N. [Specifics of legislative regulation of the individual debtor's receivership]. Predprinimatel'skoe pravo = Entrepreneurial Law, 2008, no. 1, pp. 23-29. (In Russ.)

10. Karelina S.A., Frolov I.V. [Can the citizen be qualified as bankrupt without a court-appointed financial administrator?]. Sud'ya = Judge, 2016, no. 7, pp. 10-15. (In Russ.)

\section{Conflict-of-interest notification}

I, the author of this article, bindingly and explicitly declare of the partial and total lack of actual or potential conflict of interest with any other third party whatsoever, which may arise as a result of the publication of this article. This statement relates to the study, data collection and interpretation, writing and preparation of the article, and the decision to submit the manuscript for publication. 